AJANT $\bar{A}$ 



\section{AJANT $\bar{A}$}

\section{ITS PLACE IN BUDDHIST ART}

Sheila L. Weiner

UNIVERSITY OF CALIFORNIA PRESS

Berkeley / Los Angeles / London 
University of California Press

Berkeley and Los Angeles, California

University of California Press, Ltd.

London, England

Copyright (C) 1977 by

The Regents of the University of California

ISBN 0-520-02878-3

Library of Congress Catalog Card Number: 74-22973

Printed in the United States of America 
For Myron, Beth, and Saul

"The mere recollection of these

names takes all evils away."

Āryatārānāmāsțtottaraśatakastotra 
